\title{
Smart management system for monitoring and control of infant baby bed
}

\author{
Ali Sachit Kaittan', Siraj Manhal Hameed ${ }^{2}$, Nisreen. K. Ali ${ }^{3}$, Mohammed Hasan Ali ${ }^{4}$ \\ ${ }^{1,4}$ Department of Electrical Power and Machines Engineering, University of Diyala, Iraq \\ ${ }^{2}$ Department of Computer Engineering, University of Diyala, Iraq \\ ${ }^{3}$ Department of Electrical Engineering, Heteen Secondary School, Iraq
}

\begin{tabular}{l} 
Article Info \\
\hline Article history: \\
Received Dec 24, 2019 \\
Revised Apr 2, 2020 \\
Accepted Apr 12, 2020 \\
\hline
\end{tabular}

Keywords:

Arduino

Intelligent bed

Moisture sensor

PIR sensor

Sensitive camera

\begin{abstract}
Step by step the innovation likewise becomes exceptionally quick and the human makes it. Thus, it is imperative to take care of the people to come, a unique consideration ought to be appeared to them particularly indulges. This paper manages plan and usage of intelligent child support framework which is extraordinary blessing to guardians in this century In this work a baby bed with intelligent system was be designed and implemented. Many sensors where be used to monitor the baby behavior. The component of this project consist of a smart camera, moisture sensor, sensitive Dc Motor and WiFi system.
\end{abstract} All rights reserved.

\section{Corresponding Author:}

Mohammed Hasan Ali,

Departement of Electrical Power and Machines Engineering,

Diyala University,

Diyala, Iraq.

Email: moh80mmed@gmail.com

\section{INTRODUCTION}

Inserted system is a mixture of shower equipment and programming used in the latest invention to upgrade the required function. The creativity that uses embedded structures is now seen everywhere a day [1]. Because of their busy work and lack of time, the present guardians could not spend quite a bit of their time watching their children [2]. We usually need a parent as a sheltered gatekeeper for their babies, but now creativity supports them by offering a genius child support wherever they can screen their babies [3, 4]. The system of child support with applications bears unmistakably a note that by giving camera 24 hours protection is the most significant concern in this framework. It is a strategy based on principle with the part of bringing babies happiness [5]. Our system relies on the integrated mechanism that involves watching in ways such as when the child starts to cry then the support begins to move automatically [6], if the cry lasts for more than 2 minutes at that point the message is sent to the flexible number of the parent (number included in the program during the schedule) [7, 8]. Furthermore, another unusual aspect is that when the bed of the child is wet, the message will be sent to the flexible parent and, in addition, the child's closeness in the help will also be detected using PIR sensor. What's more, camera has been associated with watch baby and its exercises with these highlights $[9,10]$.

\section{BLOCK DIAGRAM OF SYSTEM}

In order to undefstand the mechanism of baby smart bed a block diagram for this system was been ploted in Figure 1. In this system the main part is arduino board where the dicisions taking according to 
the inputs came from sensors to give two types of output: either mechanical output by the d.c motor to move the small bed, or electronic output by the sms generator to send a letter to the parents mobile to show the baby state $[11,12]$.

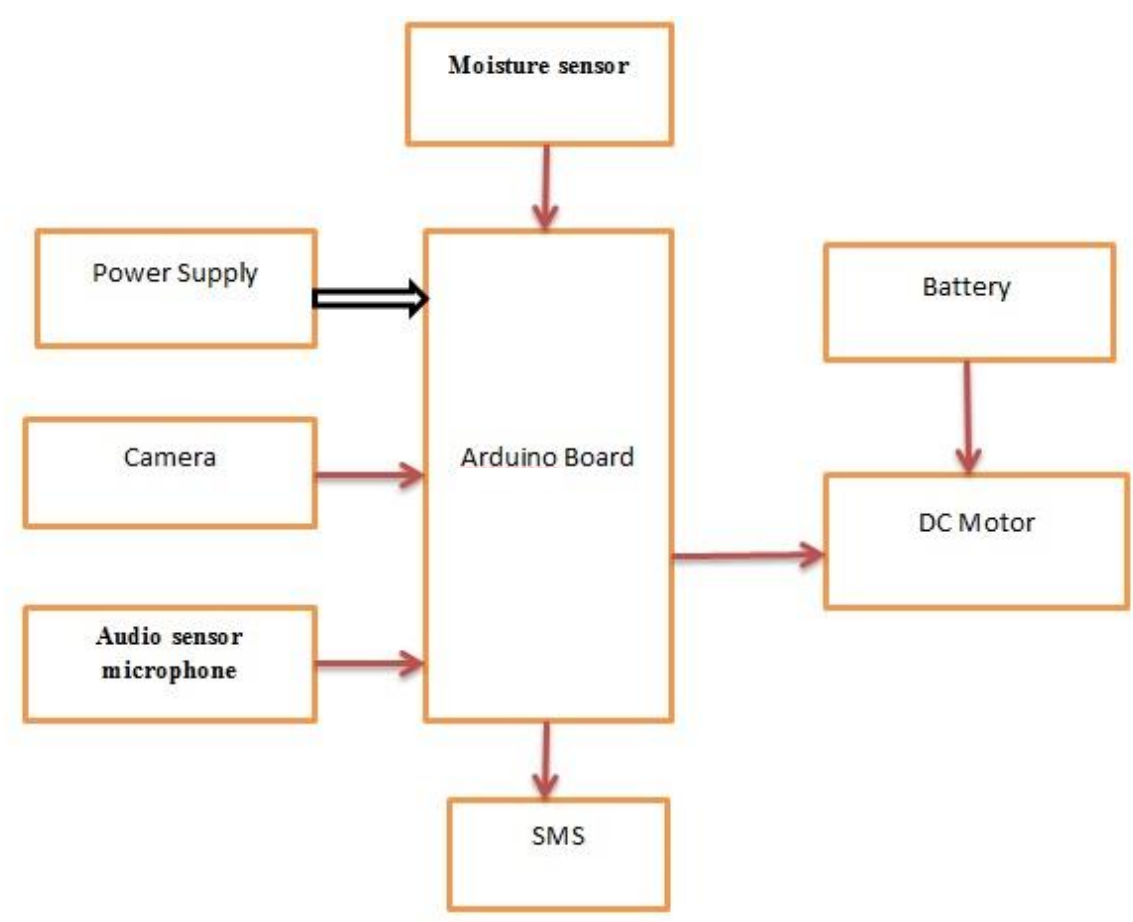

Figure 1. Block diagram

\section{WORKING PRINCIPELS}

Savvy child support work is designed as there are two modules that will illustrate the contrast of work in the system such as sound sensor and moisture sensor with highlights and job strategy. The camera will be constantly on in ON mode [13]. The SMS age technique is finished using the Web server, the SMS server approach has been used and the square outline is used to clarify how SMS is sent [14].

\section{HARDWARE DESCRIBTION}

\subsection{Arduino nano board}

An electronic advancement board speaking to the undertaking's electronic personality comprises of an open-source electronic circuit with a PC controlled microcontroller intended to encourage the utilization of intelligent hardware in multidisciplinary ventures. Arduino is chiefly utilized in the structure of intelligent e-ventures or undertakings planned for building distinctive natural sensors, for example, temperature, twist, light and weight [15]. Arduino can be associated with different projects on the PC, and depends on the open source programming language. As shown in the Figure 2 . The code for the language is like $\mathrm{C}++$ and is one of the most effortless programming dialects used to compose microcontroller programs [16].

\subsection{GSM connection unit}

GSM Global System for Mobile Communication is the technology that supports most mobile networks in the world [17]. The GSM platform is a highly successful wireless technology and an unprecedented story of global achievements and collaboration [18]. The GSM system today lives, develops and offers an extended and rich "family" of multimedia and voice services. The current network is compliant specifications in all countries of the world. The GSM module used in this project is GSM sim800L. The SIM800L is a complete and efficient cellular communication system capable of handling mobile phone segments. Sending and receiving calls and text messages as well as other features such as access to the Internet and support for GPRS. shown in the Figure 3. With this widget, we can send and receive calls and text messages and control these operations with Arduino [19]. 


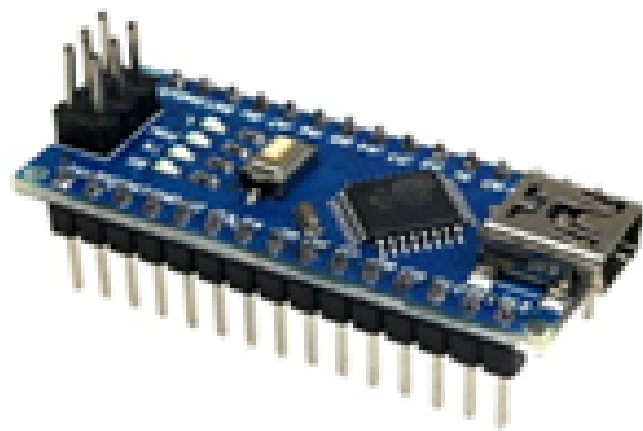

Figure 2. Arduino nano board

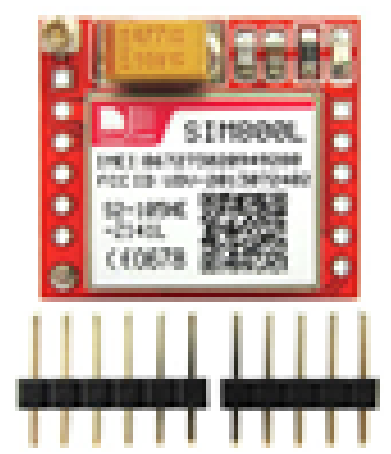

Figure 3. GSM connection unit model

\subsection{Wi-Fi}

Remote network innovation the foremost popular. Wi-Fi could be a communication strategy that creates utilize of higher frequencies to communicate as radio frequencies [20]. Wi-Fi connectors change over computerized code to transmit radio waves and the other way around to decipher the information gotten. It is based on the IEEE 802.11 determinations, which indicates how to communicate within the radio groups 2.4 and $5 \mathrm{GHz}$. There are three distinctive sorts of IEEE-classified Wi-Fi systems as 802.11a, 802.11b and $802.11 \mathrm{~g}$, and $802.11 \mathrm{n}$, the most current accessible connect. For the extend, the preferences of utilizing Wi-Fi are that Wi-Fi doesn't require wire connect [21]. Wi-Fi will interface more than one client to the same network so that data is sent and gotten. Wi-Fi, in spite of the fact that, moreover has a few drawbacks. Wi-Fi frameworks required more control to function, and progressed battery life [22]. Shown in the Figure 4.

\subsection{Audio sensor microphone}

The microphone will be placed near the baby's mouth, to record the baby's breathing sound. Since the microphone will also sense ambient noise, a bandpass filter will be used to correct this. For this reason, the bandpass filter will be designed to suppress all sounds and allow the breathing sound to pass through the filter. In the market there are so many microphones which can be used for this design. The main microphone criteria are sensitivity and relatively low signal noise [23]. Shown in the Figure 5.

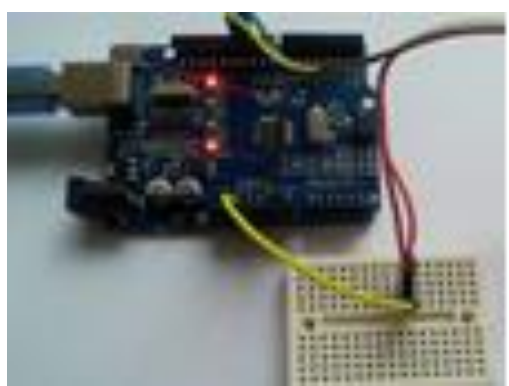

Figure 4. Wifi model

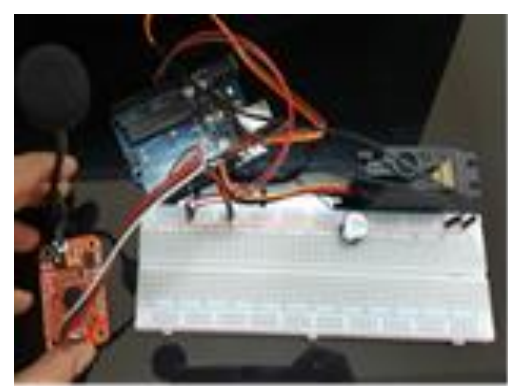

Figure 5. Audio sensor microphone model

\subsection{Moisture sensor}

The Start Fun Soil Dampness Sensor may be a basic breakout for soil dampness checking, and so on. The soil dampness sensor is reasonably clear to utilize. The two expansive uncovered cushions work as sensor tests, and act together as a variable resistor. The more water within the earth, the superior will be the conductivity between the surfaces, bringing around lower resistance and higher abdicate of SIG. To urge the Spark Fun Soil Dampness Sensor to work, you ought to essentially interface the VCC and GND pins to your Arduino-based contraption (or culminate headway board) and you will get a SIG out that depends upon the degree of water within the soil. One commonly known issue for senors with soil clamminess is their brief life hope when displayed to a wet space. To counter this we had the Gold Wrapping up PCB (ENIG or Electroless Nickel Submersion Silver) painted. For quick cabling, we propose either an fundamental 3-pin screw stick terminal or a 3-pin jumper wire get together (both can be found within the Suggested Items zone underneath) to be bound onto the sensor [24]. Moisture sensor shown in the Figure 6. 


\subsection{De motor}

The rigging engine is used in this case to swing the head. Since gear engine changes to mechanical control over the electrical power. When the child starts screaming and swings until the baby stops crying, the motor turns back swinging. The unit engine receives electrical sign from the sound sensor when the child cries then it switches to mechanical power over the sign, which results in support swing. In the necessary speed gear engine it is used to decrease the speed and retain support swinging. When baby cries for more than 2 minutes then SMS module sends the alarm to the guardians [25]. Shown in the Figure 7.

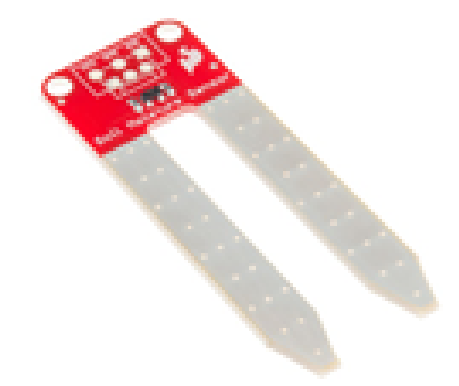

Figure 6. Moisture sensor

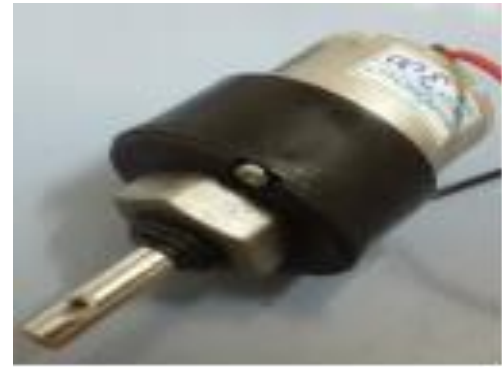

Figure 7. Dc motor

\section{RESULTS AND ANALYSIS}

In the practical part, it has viably controlled the double control handle with infant shrewd bed, sound sensor and other smartphones utilizing portable spoken to applications that have been outlined for this reason where the control and operation/shutting off the gadget itself by a association utilizing inside Wi-Fi connection. It is controlled by the IoT application. Where the same gadget is turned off or worked from any application by utilizing wifi as appeared in Figure 8. After testing seperatlly all the above componants where they successfully operate, these componants connected togather according to the block diagram shown in Figure 1 to produce the final arrangement of the baby smart bed as in Figure 9. Audio sensor code written in Figure 10.

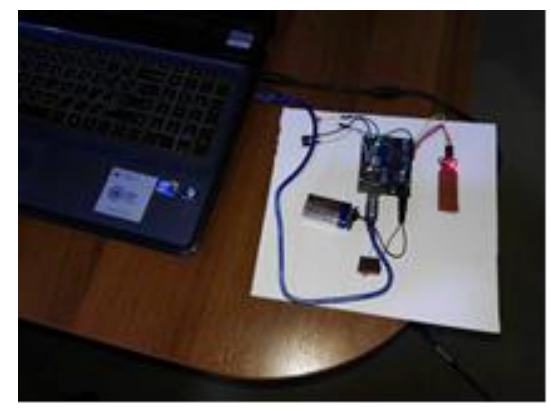

Figure 8. Wifi and moisture sensor

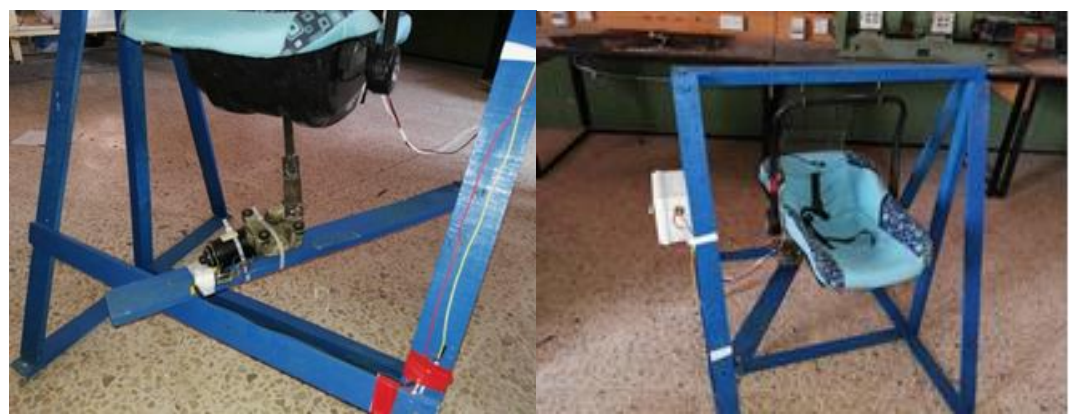

Figure 9. Final arrangement of the baby smart bed 


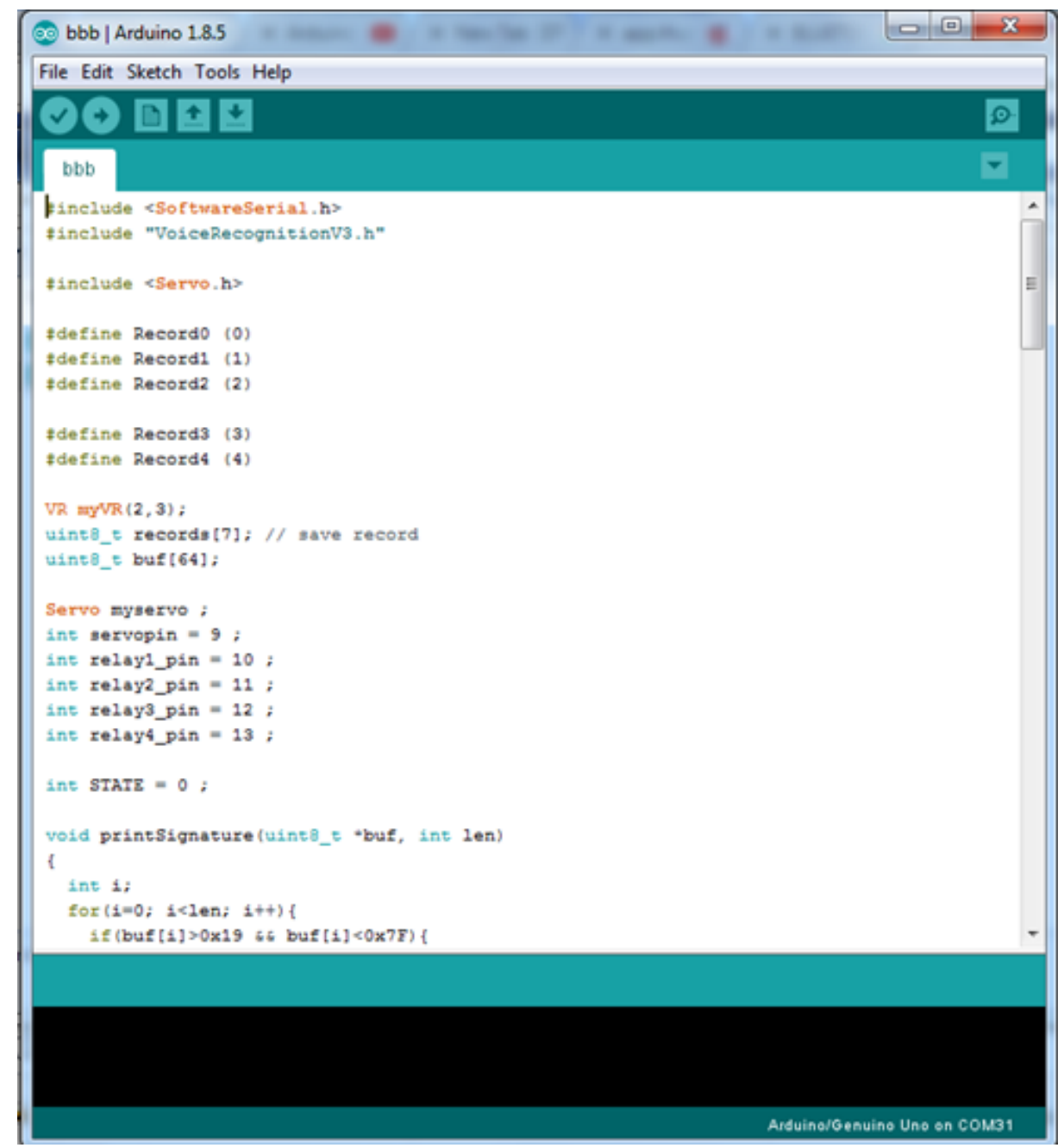

Figure 10. Code of audio sensor microphone

\section{CONCLUSION}

In the last century the science toward to simplify the live for human beings specially for child, so the smart baby bed has been developed. Due to the parents busy with working and modern life, so the smart bed with auto working become good solution for house and hospital. The results has been done show that the smart bed is a useful instrument.

\section{ACKNOWLEDGEMENTS}

This machine had been designed and implemented in the labs of department of electrical power and machines, college of ingineering, university of diyala.

\section{REFERENCES}

[1] Hsien-Tang Lin, "Implementing Smart Homes with Open Source Solutions," International Journal of Smart Home, vol. 7, no. 4, pp. 289-295, July 2013.

[2] Gowthami, Adiline Macriga, "Smart Home Monitoring and Controlling System Using Android Phone," International Journal of Emerging Technology and Advanced Engineering, vol. 3, no. 11, pp. 426-427, November 2013.

[3] A. Z. Alkar and U. Buhur, "An internet-based wireless home automation system for multifunctional devices," IEEE Transactions on Consumer Electronics, vol. 51, no. 4, pp. 1169-1174, Nov. 2005.

[4] R. Shahriyar, E. Hoque, S. Sohan, I. Naim, M. M. Akbar, and M. K. Khan, "Remote controlling of home appliances using mobile telephony," International Journal of Smart Home, vol. 2, no. 3, pp. 37-54, 2008.

[5] Sagar S. Palsodkar, Prof S. B. Patil, "Biometric and GSM Based Security for lockers," International Journal of Engineering Research and Application, vol. 4, no. 12 (Part 6), pp. 237-239, December 2014. 
[6] C. Reinisch, M. J. Kofler and W. Kastner, "ThinkHome: A smart home as digital ecosystem," 4th IEEE International Conference on Digital Ecosystems and Technologies, Dubai, pp. 256-261, 2010.

[7] R. Piyare and M. Tazil, "Bluetooth based home automation system using cell phone," 2011 IEEE 15th International Symposium on Consumer Electronics (ISCE), Singapore, pp. 192-195, 2011.

[8] A. Aditya Shankar, P. R. K. Sastry, A. L. Vishnu ram, A. Vamsidhar, "Fingerprint Based Door Locking System," International Journal of Engineering and Computer Sciences, vol. 4, no. 3, pp. 10810-10814, March 2015.

[9] M. Gayathri, P. Selvakumari, R. Brindha, "Fingerprint and GSM based Security System," International Journal of Engineering Sciences Research Technology, vol. 3, no. 4, pp. 4024-4029, April 2014.

[10] Salman, Ghassan Abdullah, Mohammed Hasan Ali, and Ali Najim Abdullah, "Implementation Optimal Location and Sizing of UPFC on Iraqi Power System Grid (132 kV) Using Genetic Algorithm," International Journal of Power Electronics and Drive Systems (IJPEDS), vol. 9, no. 4, pp. 1607-1615, 2018.

[11] Ali Sachit Kaittan, "Analysis and evaluation of power quality issues in computer-based generation system using custom power devices," International Journal of Civil Engineering and Technology (IJCIET), vol. 10, no. 4, pp. 1870-1879, April 2019.

[12] Abood, Hatim G., Ghassan Abdullah Salman, and Ali Sachit Kaittan, "A Regularized Approach for Solving IllConditioned State Estimation of Distribution Systems," Elektrotehniski Vestnik, vol. 86, no. 3, pp. 137-143, 2019.

[13] A. S. Kaittan, "Comparison study between solid and litz wires of induction cooker," 2018 1st International Scientific Conference of Engineering Sciences - 3rd Scientific Conference of Engineering Science (ISCES), Diyala, pp. 86-91, 2018.

[14] Ali, Mohammed H., "Mathematical Driving Model of Three Phase, Two Level Inverter by (Method of Interconnected Subsystem)," Iraqi Journal for Electrical And Electronic Engineering, vol. 13, no. 1, pp. 73-82, 2017.

[15] Ali, Mohammed H., "Design and Implementation of an Electrical Lift Controlled using PLC," International Journal of Electrical and Computer Engineering, vol. 8, no. 4, pp. 1947-1953, 2018.

[16] Hussein Thani Rishag, Siraj Manhal Hameed, "Improvement The Dfig Active Power With Variable Speed Wind Using Particle Swarm Optimization," Diyala Journal of Engineering Sciences, vol. 9, no. 2, pp. 12-22, June 2016.

[17] Hayder Khaleel Ibrahim AL-Qaysi, Siraj Manhal Hameed, "Enhancing the Gain and Power of Folded-cascode Amplifier using Artificial Neural Network," International Journal of Engineering Research and Technology, vol. 12, no. 7, pp. 1117-1125, 2019.

[18] H. A. Hasan, and S. M. Hameed, "Characteristics of Earth Electrodes Under High Frequency Conditions: Numerical Modelling," 3rd International Conference on Engineering Sciences, IOP Conf. Series: Materials Science and Engineering, vol. 671, 2020. doi: 10.1088/1757-899X/671/1/012043

[19] Ali, Mohammed H., "Speed Control of (Sedm) Adopting Chopper Converter and Pi Controller," Diyala Journal of Engineering Sciences, vol. 8, no. 4, pp. 355-364, 2015.

[20] Abdullah, Ali Najim, and Mohammed Hassan Ali, "Direct torque control of IM using PID controller," International Journal of Electrical and Computer Engineering (IJECE), vol. 10, no 1, pp. 617-625, 2020.

[21] Ali, Mohammed Hasan, and Qasim Al Azze, "Design and implementation a security system for bank using voice recognition," International Journal of Power Electronics and Drive Systems (IJPEDS), vol. 10, no. 4, pp. 2126-2129, 2019.

[22] Qasim Al Azze, Mohammed Hasan Ali, " Design and implement of pulse width modulation with low-cost hardware in the loop," International Journal of Power Electronics and Drive System (IJPEDS), vol. 11, no. 2, pp. 870-878, Jun. 2020.

[23] Mohammed H. Ali, Nisreen K. Ali, "IoT based security system and intelligent home automation multi monitoring and control systems," International Journal of Robotics and Automation (IJRA), vol. 8, no. 3, pp. 205-210, Sep. 2019.

[24] A. F. Symon, N. Hassan, H. Rashid, I. U. Ahmed and S. M. Taslim Reza, "Design and development of a smart baby monitoring system based on Raspberry Pi and Pi camera," 2017 4th International Conference on Advances in Electrical Engineering (ICAEE), Dhaka, pp. 117-122, 2017.

[25] Mohanraj, K., N. Balaji, and R. Chithrakkannan. "IoT Based Patient Monitoring System Using Raspberry PI 3 and LabVIEW," Pak. J. Biotechnol, vol. 14, no. 3, pp. 337-343, 2017.

\section{BIBLIOGRAPHY OF AUTHORS}

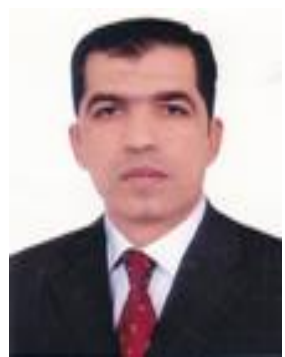

Ali Sachit Kaittan was born in Baghdad, Iraq, in 1974 received his B.Sc from University of Diyala Iraq in 2006, MSc from University of Technology Baghdad Iraq in 2012. His current research interests are power system modeling, induction heating, Electrical drives. He is teaching several basic subjects of the Electrical Engineering, University of Diyala, Iraq. 

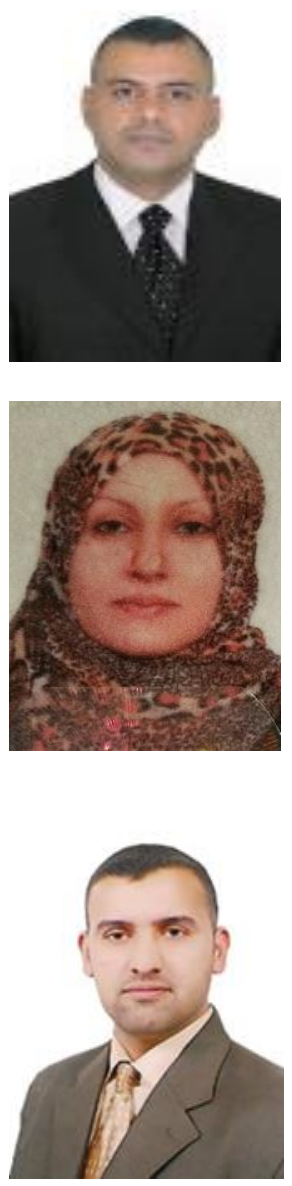

Siraj Manhal Hameed was born in Diyala , Iraq, in 1981 received his B.Sc from University of Diyala Iraq in 2004, MSc from University of Technology Baghdad Iraq in 2014. He is currently assistant lecturer at the Department of computer Engineering, College of Engineering, University of Diyala Iraq. His current research interests are power system modeling, renewable energy, Electrical drives. He is teaching several basic subjects of the computer Engineering, University of Diyala, Iraq. He has 3 published papers.

Nisreen kareem Ali received her B.Sc from University of diyala Iraq in 2006, MSc from University of Belgorod, Russia ,2013 .she is currently assistant lecturer at the Department of Electrical , Hittin Professional Prep , Diyala Iraq.

Mohammed Hasan Ali was born in Diyala, Iraq, in 1980, received his B.Sc. from University Diyala / Iraq in 2006, M. Sc. from University of Belgorod , Russia ,2013 .He is currently assistant lecturer at the Department of Electrical Power Engineering, College of Engineering, University of Diyala Iraq. Professional Strength and Skills: His current research interests are power system modeling, power quality, renewable energy and power electronics. He has 10 years experience in practice of Electrical engineering. He is teaching several basic subjects of the Electrical Engineering, University of Diyala Iraq. He has 4 published papers. 